\title{
COVID-19 - Apiphytotherapeutic opportunities for prevention and treatment
}

\author{
COVID-19 - Oportunități apifitoterapeutice de prevenție și tratament
}

\section{Cristina MUNTEANU}

Departamentul Pediatrie, Universitatea de Medicină şi Farmacie „Victor Babeş“, Timişoara

\begin{abstract}
In December 2019, the COVID-19 epidemic broke out in Wuhan (China), which soon spread worldwide, generating a pandemic that put the medical world in difficulty. In the absence of an etiological treatment and an effective vaccine, the researchers also turned their attention to alternative treatments, a series of plant molecules being analyzed by computer simulations regarding the inhibitory potential on the main proteins of SARS-CoV-2. A number of clinical trials based on traditional herbal formulas have also been initiated, especially by countries with a focus on alternative medicine.
\end{abstract}

Keywords: SARS-CoV-2, COVID-19, molecular docking, alternative medicine, phytotherapy, phytocompounds, quercetin, flavonoids, propolis, mushrooms, micronutrients

\begin{abstract}
REZUMAT
In decembrie 2019, a izbucnit in Wuhan (China) epidemia de COVID-19, care s-a extins in scurt timp la nivelul întregului glob, generând pandemia ce a pus lumea medicală în dificultate. În absența unui tratament etiologic şi a unui vaccin eficient, cercetătorii şi-au îndreptat atenția şi spre tratamentele alternative, o serie de molecule vegetale fiind analizate prin simulări computerizate in ceea ce priveşte potențialul inhibitor asupra proteinelor principale ale SARS-CoV-2. De asemenea, s-au inițiat o serie de studii clinice bazate pe formule tradiționale din plante medicinale, în special de către țări în care există o orientare spre medicina alternativă.
\end{abstract}

Cuvinte cheie: SARS-CoV-2, COVID-19, andocare moleculară, medicină alternativă, fitoterapie, fitocompuşi, quercetină, flavonoizi, propolis, ciuperci, micronutrienți

\section{INTRODUCERE}

Începând cu finele anului 2019 şi continuând până în prezent, întreaga omenire a fost pusă în faţa gestionării unei probleme de proporţii - pandemia generată de noul coronavirus - SARS-CoV-2. Apărut în Wuhan (China) în luna decembrie 2019, virusul SARS-CoV-2, înrudit cu virusurile SARS-CoV şi MERS-CoV (1), provoacă boala COVID-19. Cu un impact medical, social, economic, mass-media şi psiho-emoţional de mare însemnă- tate, noul coronavirus prezintă o contagiozitate ridicată (2) şi un polimorfism al simptomatologiei ce include de la forme asimptomatice la forme cu simptome grave, potenţial letale. Simptomele pot fi respiratorii (3), dermatologice $(4,5)$, digestive $(6,7)$, renale $(8)$, neurologice (9), psihiatrice (10) etc.

Cu o fiziopatologie complexă, principalele mecanisme implicate în infecţia cu virusul SARS-CoV-2 sunt cele imunologice şi hematologice, în formele severe de boală generându-se acea producţie exagerată de interleukine 
supranumită furtună de citokine $(11,12)$; ceea ce urmează este un răspuns inflamator grav şi serioase probleme de coagulare prin activarea cascadei coagulării (13).

Deşi populaţia pediatrică şi adulţii tineri fac forme predominant asimptomatice sau uşoare, acest lucru nu constituie o regulă, existând cazuri care au evoluat cu sindrom acut de detresă respiratorie (ARDS) sau disfuncţie multiplă de organ (MODS) $(14,15)$.

La aproape un an de la apariţia declarată oficial a primelor cazuri de infecţie cu noul coronavirus în Wuhan, China, lumea medicală nu deţine încă un tratament eficient şi etiologic. Se utilizează tratament suportiv şi simptomatic. Opţiunile actuale de tratament sunt medicamente cu efect antiviral precum antimalaricele de tipul hidroxiclorochinei (16), inhibitorii de protează utilizaţi în tratamentul infecţiei HIV de tipul combinaţiei lopinavir-ritonavir (Kaletra), alte antivirale de tipul remdesivir, favipiravir (17) ş.a. Opţiunile mai noi de tratament includ tratament cu plasmă de la persoane convalescente (18), anticorpi monoclonali antireceptor IL-6 (sarilumab, tocilizumab), anticorpi monoclonali anti-IL-6 (siltuximab) sau antagonişti de receptori de IL-1 (Anakinra) $(19,20)$. Vaccinul încă se află în stadiul studiilor clinice (21). De asemenea, o serie de micronutrienţi precum vitamina $C$, vitamina $D$, vitamina $A$, vitamina $E$, zincul, seleniul, acizii graşi Omega-3 ş.a. au fost sau sunt evaluaţi în ceea ce priveşte beneficiul adus în infecţia cu virusul SARS-CoV-2 $(22,23)$.

În absenţa unui tratament etiologic şi a multiplelor efecte adverse ale tratamentelor încercate până acum (24-29), preocupările cercetătorilor s-au orientat şi spre tratamentele alternative în încercarea de a găsi un tratament eficient împotriva infecţiei cu virusul SARS-CoV-2. Preocupările pentru un tratament alternativ pe bază de plante sunt realizate îndeosebi de ţări care au o orientare spre medicina alternativă precum China şi alte state orientale sau statele africane. Astfel, în luna septembrie 2020, experţii OMS au aprobat un protocol pentru testarea unor medicamente bazate pe plante în tratamentul COVID-19 în cadrul unor studii clinice care se vor derula în Africa (30).

\section{OBIECTIVE}

Obiectivul acestui studiu a fost identificarea unor metode alternative de prevenţie şi tratament în COVID-19.

\section{MATERIAL ŞI METODĂ}

Am căutat articole şi studii ştiinţifice care să identifice plante şi fitocompuşi cu acţiune antivirală în infecţia cu virusul SARS-CoV-2 în bazele electronice de date
PubMed, ScienceDirect şi Google Academic în perioada 1 ianuarie 2020 - 30 octombrie 2020. Am identificat astfel numeroase studii, in silico şi in vitro, mai puţin studii clinice, care au avut ca subiect de cercetare plante sau compuşi activi din plante cu acţiune antivirală în infecţia cu virusul SARS-CoV-2. De asemenea, am identificat studii care au avut ca subiect de cercetare acţiunea antivirală a propolisului, studii pe care le-am inclus în cercetarea noastră, apiterapia constituind, alături de fitoterapie, una dintre principalele metode tradiţionale de tratament. Nu am inclus în cercetarea noastră materialele care făceau referire la microbiota intestinală şi la nutriţie în prevenţia infecţiei cu SARS-CoV-2 şi ameliorarea simptomatologiei COVID-19. De asemenea, nu am inclus materialele la care se specifică faptul că nu au trecut prin procedura de peer review.

\section{REZULTATE ŞI DISCUȚII}

Tintele farmacologice în tratamentul infecţiei cu virusul SARS-CoV-2 sunt anumite proteine implicate în procedeul de replicare al virusului, precum: 3 CLpro (Mpro), PLpro, helicaza, RdRp (ARN polimeraza ARN-dependentă), proteina S (29) ş.a. De asemenea, deoarece virusul pătrunde în celulele gazde utilizând enzima 2 de conversie a angiotensinei, a fost investigată şi relaţia cu angiotensin convertaza 2 (ACE2).

Cercetările bazate pe plante şi pe compuşii lor bioactivi au selectat în primă instanţă plante medicinale cu recunoscute proprietăţi antivirale pe virusuri precum Influenza A şi B, herpes virusuri (herpes simplex tip 1 şi 2 , virusul varicelo-zosterian, citomegalvirus, Epstein- Barr), virusuri hepatitice, MERS-CoV, SARS-CoV (31-38) etc. Ulterior, cercetările au fost aprofundate prin testarea in silico a aceloraşi ţinte farmacologice vizate şi în tratamentele clasice.

Screening-ul pe scară largă al plantelor medicinale în vederea identificării compuşilor antivirali activi datează încă din anul 1952 (39). Dintre plantele cu recunoscute proprietăţi antivirale, menţionăm coacăzul negru (40-42), echinaceea (43-45), salvia (46), ceaiul verde $(47,48)$, cuişoarele $(49,50)$, busuiocul $(51)$, cătina (52), usturoiul $(53)$, ceapa $(54,55)$, ghimbirul $(49,56,57)$, turmericul $(58)$, pătlagina (59), aloea $(60)$, pelinul dulce/peliniţa (61), extractul din seminţe de struguri (62), frunzele de măslin (63), lemnul dulce (64), ciupercile de tipul Maitake (65), Shiitake (66), dar şi alte specii $(67,34)$, o serie de alge (68), plante chinezeşti (69), plante indiene $(70,71)$, lista rămânând deschisă. Dintre produsele apicole, propolisul este documentat a avea acţiune antivirală $(72,73)$.

Deoarece cercetările efectuate pe plantele medicinale au descoperit în componenţa acestora compuşi activi de ordinul zecilor şi sutelor (74), oamenii de ştiinţă au încercat să izoleze acei fitocompuşi cu potenţiale 
acţiuni farmacologice şi efecte adverse minime. Dintre compuşii activi din plante cu acţiuni antivirale, se remarcă astfel quercetina $(75,76)$, andrografolida (77), acidul glicirizic $(78)$, baicalina $(79,80)$, luteolina $(81,82)$, resveratrolul $(83,84)$, curcumina $(85-87)$, eugenolul (88), artemisinina (89), galatul de epigalocatechină (90) hesperitina (91), antocianina (92) şi multe altele.

Au fost realizate screening-uri computerizate pe numeroase plante, mai precis pe fitocompuşii activi din acestea, pentru a prezice interacţiunile dintre diferite substanţe (fitocompuşi sau medicamente) şi proteinele SARS-CoV-2. Astfel, a putut fi determinată afinitatea de legare a diferitelor substanţe faţă de ţintele moleculare ce prezintă interes în contextul noii pandemii şi au putut fi subliniate proprietăţile antivirale ale compuşilor activi din diverse plante.

O serie de medicamente pe bază de plante chinezeşti şi fitocompuşi cu acţiune antivirală, cu potenţial de a inhiba virusul SARS-CoV-2, au fost evaluate (93) vizând proteine precum proteina S (Spike), 3CLpro, PLpro, RdRp şi angiotensin convertaza 2 (ACE2). Fitocompuşii analizaţi în studiul la care facem referinţă sunt: quercetina, andrografolida, acidul glicirizic, baicalina, luteolina şi extractul alcoolic de paciuli. Studiul a prezis afinităţile de legare dintre aceşti compuşi şi ţintele farmacologice care vizează virusul SARS-CoV-2. Astfel, în urma testelor efectuate, s-a dovedit in silico faptul că quercetina, andrografolida (izolată din Andrographis paniculata), glicirizina (izolată din lemnul dulce/Glycyrrhiza glabra), baicalina (izolată din Scutellaria baicalensis), extractul alcoolic de paciuli şi luteolina inhibă 3CLpro în special, dar şi celelalte proteine: PLpro, RdRp, proteina $S$, având potenţial terapeutic în infecţia cu virusul SARS-CoV-2.

Următorul studiu (94) reprezintă o revizie de literatură sistematică şi metaanaliză, care a evaluat studii controlate randomizate ce au determinat eficacitatea în COVID-19 a medicinei chinezeşti bazate pe plante. 18 studii s-au încadrat în criteriile de includere, 5 studii multicentrice şi 13 monocentrice - studii realizate în anul 2020 în China şi publicate în limba chineză (cu excepţia unuia singur, publicat în limba engleză). 31 de medicamente chinezeşti bazate pe plante au fost utilizate în această revizuire. Cel mai des utilizate plante sunt: rădăcina de lemn dulce (Gancao, Radix Glycyrrhizae) $(48,39 \%)$, rădăcina de Scutellaria (Huangqin, Radix Scutellariae baicalensis) $(35,48 \%)$, rizomul de Pinellia (Banxia, Rhizoma Pinelliae tematae) (35,48\%), fructul de Forsythia (Lianqiao, Fructus Forsythiae suspensae) $(32,26 \%)$ şi seminţele de caise amare (Kuxingren, Semen Armeniacae amarum) (32,26\%). Ca modalitate de prezentare a remediilor, se remarcă: decoctul $(54,84 \%)$, urmat de granule $(22,58 \%)$, forma injectabilă $(12,90 \%)$, lichid pentru administrare orală $(6,45 \%)$, capsulă $(6,45 \%)$ şi tabletă $(3,23 \%)$. Eficacitatea tratamente- lor a fost evaluată într-o metaanaliză prin îmbunătăţirea semnificativă a imaginilor CT-ului pulmonar (13 studii, $n=1402$; RR = 1,23; IC 95\%: 1,15-1,32; I 2 = 31\%, $\mathrm{P}<0,00001)$. De asemenea, rata de vindecare a înregistrat o îmbunătăţire semnificativă la cei trataţi cu remediile pe bază de plante chinezeşti (7 studii, $\mathrm{n}=1523$; $\mathrm{RR}=1,18$; IC 95\%: 1,13-1,24; I 2 = 24\%, P < 0,00001) şi s-a remarcat o reducere semnificativă a duratei de spitalizare ( 2 studii, $\mathrm{n}=119$; WMD: $-1,99$; IC 95\%: $-3,28$ până la $-0,70 ; । 2=0 \%, P=0,002$ ), a simptomelor clinice (febră, tuse, oboseală) şi a markerilor inflamatori.

O formulă - Qing Fei Pai Du Tang (QFPDT) - utilizată în medicina chineză, care include 21 de plante, a fost raportată (95) a fi eficientă în COVID-19 în 10 provincii din China continentală. În acest studiu au fost analizate plante precum Ephedra sinica, Bupleurum chinense, Pogostemon cablin, Cinnamomum cassia, Scutellaria baicalensis, cu acţiune antivirală şi imunomodulatoare, implicate în prevenirea furtunii de citokine şi reglarea ACE2.

Două flavone şi o triterpenă au fost analizate (96) ca fiind eficace împotriva SARS-CoV-2, prezentând în simularea computerizată efectuată o energie de andocare mai mică comparativ cu medicamentul antiviral Indinavir. Aceşti trei fitocompuşi propuşi pentru cercetări suplimentare sunt: sodwanona B obţinută din speciile sud-africane ale buretelui marin Axinella sp., kemferol (regăsit în alimente precum varză, broccoli, roşii, fasole, struguri sau în plante medicinale precum Ginkgo biloba, Tilia spp., Acacia nilotica) şi ciclomulberrina din Morus alba $L$.

Medicina tradiţională chineză apare din nou în interesul cercetătorilor (97) cu un remediu utilizat în tratarea infecţiilor acute ale tractului respirator superior şi inferior - capsulele Shufeng Jiedu (SFJDC). Cele opt plante din compoziţia remediului - rhizoma Polygoni cuspidati, fructus Forsythiae, radix Isatidis, radix Bupleuri, herba Patriniae, herba Verbenae, rhizoma Phragmitis şi radix Glycyrrhizae - au demonstrat efecte imunomodulatoare şi antiinflamatorii prin mecanisme multiple, constituind un remediu cu potenţial antiviral în infecţia COVID-19.

Un studiu retrospectiv (98) a analizat efectul granulelor Jinhua Qinggan asupra pneumoniei cu noul coronavirus la 80 de pacienţi cu vârste cuprinse între 15 şi 86 de ani, diagnosticaţi în perioada 24 ianuarie-17 februarie 2020 în Beijing YouAn Hospital. Dintre aceştia, grupul experimental (44 de pacienţi) a primit granule Jinhua Qinggan în termen de 24 de ore de la internare, în timp ce grupul de control (36 de pacienţi) fie nu a primit granule Jinhua Qinggan, fie a luat granulele pentru mai puţin de 2 zile. Studiul a comparat durata detectării acidului nucleic viral în cele două grupuri şi timpul de recuperare pulmonară prin modificarea imaginilor la CT toracic, ambele mai mici în grupul experi- 
mental - ceea ce demonstrează eficienţa utilizării acestui remediu la pacienţii cu infecţie COVID-19.

Un alt studiu retrospectiv (99) a analizat evoluţia unui număr de 36 pacienţi internaţi în perioada 17 ianuarie 2020 - 28 ianuarie 2020 în The Fifth Affiliated Hospital of Sun Yat-sen University din Zhuhai, Guangdong, China. Studiul a urmărit eficacitatea remediilor bazate pe plante (NMH), astfel încât din cei 36 au fost selectaţi 22 pacienţi şi au fost create două grupuri, grupul experimental NMH (11 pacienţi), care a beneficiat de tratament combinat NHM cu tratament medical occidental standard, şi grupul de control (11 pacienţi), care a beneficiat doar de tratamentul medical standard. Durata febrei a fost mai mică în grupul NMH, numărul cazurilor cu diaree mai mic şi îmbunătăţirea imaginii CT toracic a fost constatată într-o perioadă mai scurtă în grupul experimental comparativ cu cel de control. Studiul concluzionează faptul că remediile bazate pe plante pot îmbunătăţi simptomele clinice ale pacienţilor cu COVID-19 şi ar putea fi eficiente în tratarea COVID-19, fiind necesară efectuarea unui studiu clinic mai larg, controlat randomizat prospectiv.

Proprietăţile plantei indiene Tinospora cordifolia, utilizată frecvent în medicina ayurvedică, au fost investigate prin screening computerizat (100). Mai exact, au fost evaluaţi fitocompuşii berberină, $\beta$-sitosterol, colină, tetrahidropalmatină şi octacosanol privind proprietăţile lor de inhibare asupra 3CLpro. Berberina a prezentat cel mai bun potenţial de inhibare al 3CLpro, urmată de $\beta$-sitosterol, octacosanol, tetrahidropalmatină, colină.

Tinospora cordifolia (Guduchi/Giloy) a constituit subiectul unor cercetări (101) şi alături de alte plante indiene precum busuiocul (Ocimum sanctum/Tulsi) şi Withania somnifera (Ashwagandha). Studiul de andocare moleculară la care ne referim a arătat şase inhibitori probabili împotriva Mpro, extraşi din aceste plante medicinale: doi din Withania somnifera (withanosida V şi somniferina), unul din Tinospora cordifolia (tinocordisida) şi trei din Ocimum sanctum (vicenina, isorientin 4'-O-glucozid 2"-O-p-hidroxibenzoat şi acidul ursolic).

Fitocompuşii din Ashwagandha şi propolis au fost analizaţi într-un studiu (102) care a examinat potenţialul de legare la proteina Mpro a SARS-CoV-2 al withaferinei-A, withanonei (withanolide active din Ashwagandha şi esterulului fenetilic al acidului cafeic (CAPE - ingredient bioactiv al propolisului). Prezentul studiu a prezis o bună afinitate de legare a acestor compuşi naturali şi potenţialul inhibitor al withanonei şi CAPE pentru proteaza Mpro a SARS-CoV-2.

Potenţialul unor flavonoide prezente în propolis de a se lega de receptorii ACE2 a fost investigat in silico (103), cuantificând constantele de legare ale acestora. Flavonoidele analizate au fost: acidul cafeic, esterul fenetilic al acidului cafeic, crisina, galangina, miricetina, rutina, hesperitina, pinocembrina, luteolina şi querce- tina. Studiul concluzionează că aceste substanţe prezintă afinitate de legare bună şi reprezintă un potenţial terapeutic în tratamentul COVID-19.

Propolisul şi Ashwaganda au constituit subiectul unui alt studiu (104), care a demonstrat potenţialul inhibitor asupra proteazei Mpro al fitocompuşilor withaferină $A$, withanonă şi al esterului fenetilic al acidului cafeic.

32 de condimente şi plante naturale au fost examinate (105), folosind procedeul de andocare moleculară, ca inhibitori pentru Mpro. Acidul salvianolic A (din Salvia officinalis) şi curcumina (din Curcuma longa) au prezentat afinităţi de legare mai bune împotriva Mpro faţă de lopinavir. Acidul salvianolic A a demonstrat o stabilitate complexă mai mare decât curcumina sau lopinavirul.

Planta indiană Azadirachta indica (Neem) a fost investigată într-un studiu (106) care a evaluat 19 compuşi extraşi din frunze (quercetina, nimbosterol/ $\beta$-sitosterol, nimbolid), flori (acid palmitic, acid oleic, linoleic acid), scoarţă (margocin, nimbidiol, nimbiona) şi seminţe (azadiradiona, fraxinellona, salannina, salannol, vepin, azadirona, gedunina, azadirachtina $\mathrm{H}$, nimbina, desacetilgedunina); aceştia au fost testaţi prin simulare computerizată şi au demonstrat acţiunea asupra PLpro. Dintre cei 19 enumeraţi anterior, desacetilgedunina (DCG) a prezentat cea mai mare afinitate de legare faţă de PLpro. În acest studiu, desacetilgedunina a prezentat o afinitate de legare mai mare decât toate medicamentele cunoscute şi active utilizate: clorochina, hidroxiclorochina, remdesivirul, ribavirina (tribavirină), favipiravirul (avigan), ritonavirul, nitazoxanida.

Un alt studiu privitor la Neem (107) a utilizat metode de andocare şi simulare computerizată pentru a identifica inhibitori ai proteinei membranare (M) şi de înveliş (E) din SARS-CoV-2. Dintre cei 70 de fitocompuşi ai plantei medicinale Azadirachta indica (Neem) analizaţi prin procedee de andocare moleculară, nimocina şi nimbolina A au demonstrat capacitatea de a inhiba activitatea proteinelor de înveliş (perturbând activitatea canalelor ionice) şi membranare ale SARS-CoV-2.

Rolul canalelor ionice ale proteinei E de înveliş a fost studiat şi în alte materiale (108), studiile efectuate până acum sugerând că activitatea acestor canale ionice este necesară pentru propagarea virusului. Fitomolecule precum belachinal, bacaflavanona $E$ şi vibsanol $B$ au fost documentate (109) ca având rol în restricţionarea canalelor ionice ale proteinei $E$ de înveliş $a$ SARS-CoV-2, reducând mişcarea de îndoire a membranei şi diminuând astfel patogeneza virusului.

Planta indiană Justicia adhatoda a constituit subiectul unei alte cercetări (110), care a identificat în frunzele acesteia şase alcaloizi (vasicolină, vasicolinonă, vasicinonă, vasicină, adatodină şi anizotină) care interacţionează cu proteina Mpro a SARS CoV-2. Dintre 
aceştia, anizotina este compusul care a interacţionat cel mai puternic, complexul Mpro-anizotină fiind mai stabil decât complexul Mpro-darunavir/lopinavir. Din aceste motive, anizotina a fost propusă pentru a inhiba activitatea proteolitică a proteazei Mpro.

Zece plante indiene au fost investigate (111) în ceea ce priveşte acţiunea fitocompuşilor lor asupra Mpro şi a proteinei $S$ a noului coronavirus, precum şi a receptorului ACE2. S-au remarcat cucurbitacina $E$, orientina, bis-andrografolida, cucurbitacina $B$, isocucurbitacina $B$, vitexina, berberina, acidul brionolic, piperina şi magnoflorina cu proprietăţi inhibitoare virale.

Broussonetia papyrifera (dud japonez) a fost analizată într-un studiu in silico (112), care a identificat în componenţa sa polifenoli cu rol inhibitor pentru proteaza Mpro/3CLpro a SARS-CoV-2. Studiul a plecat de la raportările deja existente ale eficienţei polifenolilor din Broussonetia papyrifera în interacţiunea cu proteazele SARS-CoV şi MERS-CoV (113). Simulările dinamicii moleculare au arătat că toate complexele Mpro-polifenol analizate au prezentat o afinitate de legare mai mare şi, în concluzie, sunt mai stabile decât complexul Mprodarunavir/lopinavir.

Opt diterpene (18-hidroxferruginol, hinokiol, ferruginol, 18-oxoferruginol, O-acetil-18-hidroxferruginol, metil dehidroabietat, acid izopimaric, kayadiol) şi patru biflavonoide (amentoflavonă, bilobetină, ginkgetin, sciadopitysină) din frunzele plantei Torreya nucifera au fost evaluate (114) ca potenţiali inhibitori ai proteazei Mpro a SARS CoV-2. Studiul a relevat faptul că trei biflavonoide ale $T$. nucifera (amentoflavona, bilobetina şi ginkgetinul) au o afinitate de legare mai puternică decât inhibitorul N3 şi lopinavir faţă de Mpro şi pot acţiona astfel ca inhibitori pentru SARS-CoV-2.

Proprietatea unor fitoestrogeni de a inhiba virusul SARS-CoV-2 a fost investigată (115) prin testarea moleculelor din plante în relaţia cu proteina de şoc termic A5 de la suprafaţa celulelor (HSPA5). Rezultatele cercetării arată o afinitate de legare ridicată pentru fitoestrogeni (diadiazina, genisteina, formonteina şi biocianina A din Cicer arietinum - năut), acid clorogenic (găsit în cafea), acid linolenic (extras din uleiurile vegetale precum canola, soia, seminţe de in, măsline şi unele nuci), acid palmitic, acid cafeic (găsit în multe surse, inclusiv fructe de pădure, ierburi, ciuperci şi boabe de cafea), hidroxitirosol (găsit în uleiul de măsline extravirgin), acid cis-p-cumaric (găsit în ciuperci, alune, roşii şi usturoi), cinamaldehidă (găsită în Cinnamomum verum), timochinonă (seminţe de Nigella sativa).

Planta de ceai (Camellia sinensis L.) a constituit obiectul unui studiu (116) ce a selectat moleculele bioactive din componenţa sa cu acţiune inhibitoare asupra proteazei Mpro a SARS-CoV-2. Fitomoleculele oolonghomobisflavan-A, teasinensin-D şi teaflavin-3-O-gallat au prezentat în simularea computerizată realizată sco- ruri de andocare mai mari decât medicamentele atazanavir, darunavir şi lopinavir.

De asemenea, opt polifenoli din ceaiul verde au fost investigaţi (117) într-un studiu in silico ca potenţiali inhibitori ai proteazei Mpro. Dintre aceştia, trei - şi anume epigallocatechin gallat (EGCG), epicatechin gallat (ECG) şi gallocatechin-3-gallat (GCG) - au prezentat o afinitate de legare mai mare decât inhibitorul de protează N3.

Flavonoidele din ceaiul verde (Camelia sinensis) au fost selectate într-un alt studiu (118), care a urmărit testarea rolului acestora în procesul de legare al glicoproteinelor SARS-CoV-2 de receptorul celulei gazdă ACE2. Dintre moleculele selectate, epigallocatechin gallat (EGCG), teaflavin digallat (TFDG) şi teaflavin monogallat (TFMG) au demonstrat o afinitate mult mai mare faţă de proteina virală S în comparaţie cu hidroxiclorochina.

Câţiva metaboliţi naturali secundari, între care delfinidin 3,5-diglucozid, scutellarein 7-glucozid, avicularina şi acidul 3,5-di-O-galloylshikimic, au fost analizaţi in silico (119) în ceea ce priveşte afinitatea de legare faţă de proteaza Mpro a noului coronavirus şi receptorul ACE2 al celulei gazdă. Fitocompuşii au prezentat afinitate de legare bună, însă cercetarea subliniază o biodisponibilitate orală slabă a acestora, sugerând necesitatea încorporării acestora în nano/microparticule enterorezistente.

Plantele medicinale africane au ridicat şi ele interesul cercetătorilor într-un studiu (120) care a analizat 62 alcaloizi şi 100 terpene ca potenţiali inhibitori ai 3CLpro. Dintre aceştia, şapte (10-hidroxiusambarensină, criptoquindolină, 6-oxoisoiguesterină, 22-hidroxihopan-3-onă, criptospirolepină, izoiguesterină, acid 20- epi brionolic) au prezentat afinitatea de legare cea mai bună pentru 3CLpro în procedeul de simulare computerizată.

Câteva plante marocane au fost analizate (121) ca inhibitori împotriva proteazei principale a SARS-CoV-2. Dintre cele 67 de molecule naturale analizate, trei crocina (Crocus Sativus L.), digitoxigenina (Nerium Oleander) şi $\beta$-eudesmol (Lauris Nobilis L.) - au fost propuse ca inhibitori ai noului coronavirus, cu o afinitate de legare bună faţă de proteaza principală a SARS-CoV-2.

Studiul următor (122) a selectat 40 de fitocompuşi cu acţiune antivirală, urmărind să demonstreze prin procedee de andocare moleculară interacţiunea acestora cu proteaza principală a SARS-CoV-2. Din numărul iniţial de compuşi s-au remarcat hipericina, cianidina 3-glucozida, baicalina, glabridina şi $\alpha$-cetoamida-11r, care ar putea fi utilizate ca inhibitori pentru 3CLpro.

O serie de fitocompuşi din plante şi condimente indiene, precum şi un preparat ayurvedic Anupana, au fost urmăriţi într-un studiu in silico (123) ca potenţiali 
inhibitori ai proteinelor SARS-CoV-2 şi ai angiotensin convertazei 2. Rezultatele de andocare şi simulare computerizată au indicat faptul că epicatechina, embelina, hesperidina, cafestolul, murraianina şi murrayaquinona-A prezintă o eficacitate mai mare a inhibării proteinelor noului coronavirus decât hidroxiclorochina, remdesivirul şi ribavirina. Preparatul Anupana a fost inclus în studiu datorită faptului că are în componenţă epicatechină, hesperidină şi mangiferină. Cei cinci inhibitori enumeraţi anterior se regăsesc în plante şi condimente precum: mentă, ceai, frunze de curry, cacao, citrice, struguri, piper negru fals (Embelia ribes).

Un alt material (124), de data aceasta un studiu in vitro, ne demonstrează efectul antiviral al remdesivirului, lopinavirului, homorringtoninei şi emetinei împotriva virusului SARS-CoV-2. Remdesivirul inhibă replicarea SARS-CoV-2 în celulele Vero-E6 cu EC 50 la 23,15 $\mu \mathrm{M}$. Lopinavirul inhibă replicarea SARS-CoV-2 cu EC 50 la 26,63 $\mu \mathrm{M}$. Homoharringtonina şi emetina inhibă replicarea SARS-CoV-2 cu EC 50 la 2,55 şi respectiv 0,46 $\mu \mathrm{M}$. În acest studiu, s-a observat in vitro o acţiune sinergică a combinaţiei remdesivir - emetină, cu obţinerea unei inhibări de $64,9 \%$ a randamentului viral.

100 de polifenoli naturali au fost selectaţi pentru a evalua (125) prin andocare moleculară potenţialul lor de a acţiona ca inhibitori ai RdRp a SARS-CoV-2. Dintre polifenolii selectaţi, teaflavina, teaflavin-3'-O-galat, teaflavin-3'-gallat, teaflavin 3,3'-digalat, hesperidina, EGCG, miricetina şi quercetagetina au prezentat o afinitate bună de legare faţă de RdRp. În plus, EGCG (polifenol din ceaiul verde), teaflavin-3'-O-galat, teaflavin-3'galat şi teaflavin $3,3^{\prime}$-digalat posedă o afinitate de legare mai bună decât remdesivirul faţă de RdRp.

Lemnul dulce este planta care a trezit atenţia a numeroşi cercetători, fapt care se reflectă în studiile rezultate (126-137). Acidul glicirizic izolat din o varietate chinezească a lemnului dulce (Glycyrrhiza uralensis Fisch.) a prezentat un scor de andocare bun în simulările computerizate efectuate (126) şi a influenţat interacţiunea dintre proteina S şi ACE2, sugerând astfel o activitate antivirală faţă de SARS-CoV-2.

20 de molecule active din lemnul dulce au fost investigate (127) privind interacţiunea cu proteina ţintă a SARS-CoV-2. Dintre aceştia, şase fitocompuşi - acid glicirizic, izolicviritin-apiozidă, glasperină $A$, lichiritină, 1-metoxifazolidină şi hedisarimcumestan $B$ - au prezentat o bună afinitate faţă de proteina virală Mpro, recomandându-le astfel ca o alternativă în terapia împotriva COVID-19.

Un alt material (128) descrie simulările computerizate efectuate pe molecule active din lemnul dulce împotriva diferitelor ţinte proteice ale noului coronavirus precum proteina S şi Nsp15. Conform acestui studiu, acidul glicirizic, dehidrogliasperinda C, licviritina, glyasperina $A$, izolicviritin-apiozida şi licocalcona $D$ au pre- zentat cele mai bune energii de legare, majoritatea mai bune decât ribavirina şi lopinavirul. În plus, acidul glicirizic a perturbat conexiunea virusului cu receptorul ACE-2 la pătrunderea în celula gazdă, în timp ce glasperina $\mathrm{A}$ a inhibat procesul de replicare a virusului după intrarea acestuia în celulă - ceea ce le recomandă a fi soluţii utile împotriva COVID-19. Acidul glicirizic a demonstrat proprietăţi inhibitoare împotriva proteinei $S$ a SARS-CoV-2 şi într-un alt studiu (129), fiind recomandat a fi utilizat în tratarea COVID-19.

Un studiu clinic randomizat (130), de această dată, a investigat efectele extractului din rădăcina de lemn dulce (Glycyrrhiza glabra L.), comparativ cu regimul terapeutic obişnuit abordat la pacienţii cu COVID-19 confirmat, cu simptome moderate. Studiul s-a desfăşurat la Spitalul Shahid Mohammadi, Bandar Abbas, Iran, şi a inclus un total de 60 de participanţi. Recrutarea a început pe 30 iulie 2020 şi se preconiza că va fi finalizată până pe 30 octombrie a.c. La data întocmirii cercetării noastre, încă nu a fost publicat rezultatul acestui studiu, pe care îl aşteptăm cu interes.

Un alt material (131), care a acordat atenţie glicirizinei din lemnul dulce, menţionează două studii clinice înregistrate pe site-ul Chinese Clinical Trial Registry. Primul (132) este un studiu clinic intervenţional (ChiCTR2000029768), care a inclus 60 pacienţi cu pneumonie în cadrul COVID-19, cu vârste cuprinse între 18 şi 75 ani, cărora li s-au administrat per os 3 capsule enterice de 150 mg glicirizină (glicirinizat de amoniu)/zi în combinaţie cu 1 tabletă de $500 \mathrm{mg}$ vitamina C/zi. Al doilea studiu (133) a inclus 100 pacienţi (ChiCTR2000030490) cărora li s-au administrat per os capsule enterice de glicirizină (nu se precizează doza) şi apă hidrogenată.

154 limonoide şi triterpene din neem, tulsi, citrice, lemn dulce şi măsline au fost analizate (134) prin simulare computerizată ca potenţiali inhibitori ai proteinelor ţintă ale SARS-CoV-2: 3CLpro, PLpro, SGp-RBD (domeniul de legare la receptorul glicoproteinei), RdRp şi ACE2. Rezultatele au demonstrat faptul că fitocompuşi precum acidul glicirizic, limonina, 7-deacetil-7-benzoilgedunina, acidul maslinic, acidul corosolic, obacunona şi acidul ursolic s-au dovedit a fi eficienţi împotriva proteinelor ţintă ale SARS-CoV-2.

Un alt studiu (135) a investigat acţiunea antivirală a derivaţilor de resveratrol împotriva activităţii PLpro şi RdRp, concluzionând că toţi derivaţii au scoruri de andocare bună şi proprietăţi inhibitoare virale, ce îi recomandă ca remedii în infecţia COVID-19.

Glicirizina, triptantrina, reina şi berberina au fost investigate într-un alt material (136) prin metode de simulare computerizată, cercetarea dovedind faptul că aceste fitomolecule prezintă un grad mare de interacţiune cu proteaza virală Mpro, ceea ce le recomandă ca potenţiali inhibitori ai proteazei principale a noului coronavirus. 
Nu în ultimul rând, merită să amintim cercetările (137) efectuate pentru crearea unor măşti din materiale biodegradabile în prevenirea răspândirii noului coronavirus. Prezentul studiu a urmărit proiectarea şi fabricarea unei măşti antivirale din trei straturi, folosind extract din rădăcină de lemn dulce; lemnul dulce conţine acid glicirretinic şi glicirizină, cu proprietăţi antivirale. Studiul a demonstrat proprietăţile de captare şi inhibare ale rădăcinii de lemn dulce asupra coronavirusului. Dimensiunea porilor de $75 \mathrm{~nm}$ este mai mică decât dimensiunea SARS-CoV-2, fapt care o recomandă în prevenirea răspândirii virusului.

Nouă flavone şi o saponină, izolate din planta africană Cleome amblyocarpa, au fost studiate într-o altă cercetare (138), prezentând afinitate de legare bună faţă de proteaza principală a virusului şi moduri de legare mai bune decât inhibitorul N3.

Următorul studiu (139) analizează fillirina (KD-1), un ingredient extras din planta Forsythia suspensa, cu dovedite proprietăţi antiinflamatoare. Studiul a evaluat in vitro eficiența antivirală şi antiinflamatoare a KD-1 împotriva unui izolat clinic de SARS-CoV-2 şi a coronavirusului uman 229E (HCoV-229E) pentru a explica mecanismele de tratament ale inflamaţiei induse de virus. Rezultatele au demonstrat că KD-1 a exercitat un efect antiviral asupra SARS-CoV-2 şi HCoV-229E, inhibând replicarea într-o manieră dependentă de doză. De asemenea, KD-1 a inhibat puternic expresia citokinelor proinflamatorii in vitro şi a scăzut semnificativ expresia proteinelor cheie legate de calea de semnalizare NF-кB.

37 de compuşi vegetali, izolaţi din remediile ayurvedice Kabasura Kudineer Chooranam şi JACOM, au fost analizaţi in silico (140), rezultatul studiului concluzionând că nouă dintre aceşti compuşi (magnoflorină, 5-hidroxi-7,8-dimetoxiflavanonă, tinospononă, cirsimaritină, crisoeriol, 6-metoxigenkwanină, vasicinonă, quercetină şi luteolină) au cea mai mare afinitate de legare cu proteina S a SARS-CoV-2. Pe baza acestor cercetări, şase plante medicinale (Sida acuta, Adhatoda vasica, Andrographis paniculata, Tinospora cordifolia, Costus speciosus, Plectranthus ambonicus) care conţin aceşti nouă compuşi au fost propuse pentru un preparat numit „SNACK-V“ cu propiretăţi inhibitoare în lupta cu noul coronavirus.

Biscoclaurina, norreticulina, amentoflavona, licoricidina şi miricetina au constituit obiectul cercetării într-un alt studiu in silico (141), dintre acestea remarcându-se în special biscoclaurina şi norreticulina, biscoclaurina demonstrând $o$ afinitate de legare mai mare pentru ţintele 3CLpro şi PLpro, în timp ce norreticulina pentru PLpro şi proteina S.

Nigella sativa (chimen negru), Trigonella foenumgraecum (schinduf) şi Anona muricata (graviola), plante medicinale cu proprietăţi antivirale dovedite, au fost examinate într-un studiu (142) care a analizat 38 mole- cule active. Dintre acestea, opt - apigenină, kemferol, luteolină, ditimochinonă, naringenină, nornuciferină, quercetină şi nigelidină - au dovedit o bună activitate inhibitoare faţă de 3CLpro.

Nigella sativa a trezit atenţia cercetătorilor într-un studiu clinic (143), care a investigat eficacitatea suplimentării cu ulei de chimen negru la pacienţii cu boală coronariană uşoară în cadrul COVID-19. Au fost selectaţi pentru prezentul studiu pacienţi cu COVID-19 formă uşoară (cu simptome de infecţie a tractului respirator superior în absenţa semnelor clinice sau radiologice ale pneumoniei). Recrutarea a fost începută pe 21 mai 2020, iar data de finalizare preconizată este 31 decembrie 2020.

Un studiu efectuat pe plante medicinale arabe (144) relevă faptul că acidul betulinic, silibinina, acidul oleanolic şi epigalocatechin-3-galat au demonstrat prin procedee de simulare virtuală afinitate mai mare faţă de proteaza Mpro decât inhibitorul N3, clorochina şi hidroxiclorochina. De asemenea, atropina, apigenina, quercetina şi shogaolul au prezentat o energie de legare mai mică decât clorochina şi hidroxiclorochina, dar mai mare decât N3.

Embelina din Lysimachia punctata şi Embelia ribes a fost evaluată (145) în ceea ce priveşte capacitatea de inhibare asupra proteazei 3CLpro, demonstrând proprietăţi antivirale pe SARS-CoV-2.

65 de compuşi din plante medicinale africane cu proprietăţi antivirale au fost selectate (146) pentru a fi investigate in silico în ceea ce priveşte potenţialul lor terapeutic în contextul pandemiei actuale. 3-galoilcatechina, proantocianidina B1 şi luteolina 7-galactozida regăsite în migdale (Terminalia catappa), struguri (Vitis vinifera) şi verbenă comună (Verbena officinalis) - se remarcă în acest studiu ca potenţiali inhibitori ai SARS-CoV-2.

Un alt studiu (147) a investigat in silico fitocompuşii din Asparagus racemosus, demonstrând că asparosida$C$, shatavarina-I, asparosida- $D$, ahatavarina- $X$ şi racemosida-A prezintă cele mai scăzute energii libere de legare la receptorul proteinei S a SARS-CoV-2, în timp ce asparosida-C, asparosida-F, rutina, asparosida-D, racemosida-A - cu Nsp15. Studiul de andocare sugerează că asparosida-C prezintă interacţiuni de legare favorabile şi scoruri bune de andocare în comparaţie cu medicamentul de referinţă remdesivir.

Sute de fitocompuşi din zece plante medicinale (Rheum emodi, Thymus serpyllum, Cymbopogon citrates, Moringa oleifera, Thalictrum foliolosum, Berberis aristata, Piper nigrum, Allium sativum, Myristica fragrans şi Zanthoxylum armatum) au fost investigaţi in silico (148) ca potenţiali inhibitori ai fosfoproteinei nucleocapsidice a SARS-CoV-2. Dintre numeroşii compuşi analizaţi, emodina, aloe-emodina, antrrarufina, alizarina şi dantronul (Rodium emodi) au prezentat o bună 
afinitate de legare la toate cele trei situsuri active diferite ale domeniului $\mathrm{N}$-terminal al proteinei nucleocapsidei SARS-CoV-2 şi pot preveni asamblarea particulelor virale, fapt care le indică drept molecule cu potenţial antiviral în infecţia cu SARS-CoV-2.

Mai mulţi derivaţi de antocianină au fost analizaţi (149) ca potenţiali agenţi antivirali împotriva proteazei Mpro a SARS-CoV-2. Şase dintre numeroşii compuşi analizaţi au prezentat rezultate de andocare bune şi proprietăţi inhibitoare asupra Mpro.

Într-un alt studiu (150), fitocompuşi precum acidul asiatic, avicularina (quercetina-3-O- $\alpha$-L-arabinofuranozida), guajaverina (quercetina 3-arabinopiranozidă) şi withaferina au fost analizaţi privind activitatea împotriva proteazelor principale ale SARS-CoV-2, demonstrând energii minime de legare şi scor de andocare bun.

Efectele ghimbirului au fost investigate într-un studiu clinic randomizat, dublu-orb, controlat cu placebo (151), care a urmărit efectele acestuia asupra manifestărilor clinice şi a caracteristicilor paraclinice ale pacienţilor cu sindrom respirator acut sever datorat infecţiei COVID-19. Studiul s-a desfăşurat la Spitalul Shahid Mohammadi, Bandar Abbas, Iran, pe un lot de 84 participanţi împărţiţi în două grupuri a câte 42 pacienţi. Grupul experimental a beneficiat de tratamentul standard pentru COVID-19, împreună cu comprimatele pe bază de ghimbir în doză de 1000 mg de trei ori pe zi, pentru o perioadă de 14 zile (152). Grupul de control a primit tratamentul standard pentru COVID-19, împreună cu comprimatele placebo de trei ori pe zi pentru o perioadă de sapte zile. Recrutarea a început pe 21 iulie 2020 şi se preconiza că va fi finalizată până la 30 octombrie 2020. La data întocmirii acestui material, încă nu au fost făcute publice rezultatele acestui studiu.

Planta Aframomum melegueta a fost analizată într-un studiu (153) ce a investigat proprietatea a o sută de metaboliţi de a inhiba 3CLpro, Nsp16 şi interfaţa de legare a glicoproteinei de suprafaţă cu receptorul ACE2. Dintre aceste molecule, diarilheptanoidul (letestuianin A), fenilpropanoidul, flavonoidele (quercetină, apigenină şi tectochrysină) au fost identificate ca fiind cu afinitate mare legare la ţintele SARS-COV-2.

Un studiu in silico (154) a examinat potenţialul uleiurilor esenţiale în lupta cu noul coronavirus şi a urmărit interacţiunea unor componente extrase din acestea cu proteinele cheie ale SARS-CoV-2: Mpro, Nsp15, ADRP, RdRp, rS şi hACE2. Astfel, cele mai bune scoruri de andocare le-au demonstrat compuşi sesquiterpenici precum $\alpha$-farnesen, $\beta$-farnesen şi farnesol. Studiul concluzionează, totuşi, că aceste energii de andocare sunt mai slabe comparativ cu energiile de andocare faţă de alte proteine, ceea ce nu le-ar recomanda ca agenţi chimioterapici viabili în infecţia cu SARS-CoV-2. Cu toate acestea, componentele uleiurilor esenţiale pot acţiona sinergic şi uleiurile esenţiale pot potenţa alţi agenţi antivirali sau pot oferi o diminuare a simptomelor COVID-19.

Plantele medicinale Momordica charantia L. şi Azadirachta indica au fost investigate prin următorul screening virtual (155) în ceea ce priveşte potenţialul lor inhibitor împotriva proteazei Mpro. Dintre cei 86 de fitocompuşi, şase - momordicină, deacetilnimninenă, margolononă, momordiciodă F2, nimbandiol, 17-hidroxiazadiradionă - au fost examinaţi şi comparaţi cu trei medicamente de referinţă în noul context epidemiologic (remdesivir, hidroxiclorochină şi ribavirină), demonstrând interacţiuni puternice şi stabile cu resturile de aminoacizi din situsul activ al Mpro. În acest studiu, doi dintre fitoliganzi, momordicina şi momordicioda F2, au prezentat o energie liberă de legare mai mare în comparaţie cu ribavirina, remdesivirul şi hidroxiclorochina.

Nicotina şi cofeina au fost studiate in silico (156) în ceea ce priveşte interacţiunea proteinei S cu receptorul uman al enzimei de conversie a angiotensinei 2 (ACE2). Simulările computerizate au relevat blocarea eficientă a ACE2 împotriva SARS-CoV-2 de către cofeină şi nicotină.

Următorul material (157) a investigat o potenţială interacţiune între proteina S a SARS-CoV-2 şi sistemul colinergic nicotinic ( $\mathrm{nAChRs)}$. Sistemul colinergic nicotinic a fost identificat ca fiind un modulator important al răspunsului inflamator, iar acest studiu a precizat o interacţiune directă între SARS-CoV-2 şi nAChRs, fapt ce poate perturba activitatea acestor receptori şi întreruperea căii antiinflamatorii colinergice.

Un agent hemostatic (Ankaferd Blood Stopper, ABS) aprobat şi utilizat în managementul sângerărilor postchirurgicale sau dentare şi pentru vindecarea rănilor inflamatorii ale mucoasei, precum şi în mucozita orală severă indusă de chimio/radioterapie la pacienţi pediatrici şi adulţi - a fost analizat într-un studiu (158) privind potenţialul său terapeutic în mucozita asociată COVID-19. ABS este un agent hemostatic topic de origine vegetală ce are în compoziţie un amestec standardizat de T. vulgaris, G. glabra, V. vinifera, A. officinarum şi $U$. dioica. Pe baza proprietăţilor $A B S$, studiul emite ipoteza utilizării topice a unei soluţii diluate pentru gargară în mucozita asociată COVID-19 şi chiar utilizarea acesteia prin nebulizare sau administrare pe cale endobronşică în fazele incipiente ale infecţiei cu SARS-CoV-2 (experienţă clinică în hemoragiile mucoasei pulmonare şi hemoptizia severă rezistentă controlate prin administrarea endobronşică de ABS). Studii anterioare au demonstrat acţiunea $A B S$ asupra receptorului proteinei $C$ endoteliale (EPCR) şi a inhibitorului activatorului plasminogen-1 (PAI-1) în celulele endoteliale ale venei ombilicale umane. Moleculele EPCR şi PAI-1 sunt considerate ca asociaţii PAR (receptori activaţi cu proteinază) în mai multe condiţii patologice. PAR-1 este principalul receptor funcţional al trombinei; el mediază agregarea 
plachetară indusă de trombină, precum şi interacţiunea dintre inflamaţie, coagulare şi răspunsul fibrotic aspecte semnificative regăsite în fiziopatologia infecţiei cu noul coronavirus. Studiul concluzionează că PAR-1 poate reprezenta o potenţială ţintă terapeutică în tratamentul COVID-19, în timp ce ABS ar putea fi un bun candidat pentru tratamentul COVID-19, datorită efectului său antagonist al PAR-1.

Nu în ultimul rând, următorul material (159) a investigat calea inhalatorie de administrare a unor substanţe volatile în afecţiunile pulmonare şi potenţialul său în complicaţiile la acest nivel asociate COVID-19. Una dintre plantele frecvent utilizate în acest sens este eucaliptul, uleiul esenţial de eucalipt fiind menţionat în farmacopeile europene şi fiind utilizat în mod tradiţional ca mucolitic, antiseptic al căilor respiratorii, recomandat în tratamentul astmului, febrei, gripei, bronşitei şi tusei convulsive. Eucaliptolul (1,8-cineolul) este principalul monoterpen al uleiului esenţial de eucalipt, dovedit în studii in vitro cu proprietăţi antivirale, bronhodilatatoare, îmbunătăţirea clearance-lui mucociliar şi inhibarea eliberării de citokine proinflamatorii. Materialul enumeră studii anterioare, in vitro şi in vivo, care au relevat aceste proprietăţi în urma administrării orale sau prin nebulizare a eucaliptolului, recomandând această moleculă pentru cercetarea în tratamentul afectării pulmonare din infecţia COVID-19.

$\mathrm{Au}$ fost propuse soluţii bazate pe plante inclusiv pentru fibroza pulmonară post infecţie COVID-19, fiind analizate (160) mai multe tipuri de polizaharide cu proprietăţi în acest sens. Producţia în exces de TGF- $\beta 1$ (factorul de creştere şi transformare $\beta 1$ ) a fost recunoscută ca fiind cel mai relevant element legat de progresul fibrozei pulmonare. Polizaharide din plante precum Angelica sinensis, Panax ginseng, Dendrobium officinale, Radix astragali au demonstrat diminuarea expresiei TGF şi a inflamaţiei alveolare în studii anterioare. Studiul de faţă a analizat acţiunea unui număr de polizaharide din plante medicinale, din anumite alge şi ciuperci şi a demonstrat activitatea lor antifibrotică, recomandându-le astfel ca agenţi alternativi pentru prevenirea sau tratarea fibrozei pulmonare la pacienţii cu COVID-19.

Următorul studiu (161) a explorat posibilitatea producerii RBD al proteinei $S$ şi a anticorpului monoclonal anti-SARS-CoV (mAb) CR3022 în planta Nicotiana benthamiana. RBD produs de plante a demonstrat legarea specifică de ACE2. mAb CR3022 produs din plante a prezentat legare de proteina RBD a SARSCoV-2, dar nu a reuşit să neutralizeze virusul in vitro. Dată fiind capacitatea plantelor de a asambla anticorpi şi antigeni funcţionali, precum şi viteza rapidă de producţie a proteinelor funcţionale, sistemul de exprimare al plantelor pentru producerea rapidă de RBD şi mAb CR3022 ar putea fi aplicat în producerea unui vaccin este concluzia acestei cercetări. Probabilitatea creării unui vaccin pe bază de fitomolecule, în speţă pe nicotină, extrasă din planta Nicotiana benthamiana, o rudă apropiată tutunului, a fost deja lansată (162).

\section{CONCLUZII}

În acest material, am încercat să realizăm o prezentare a celor mai interesante şi de actualitate studii şi articole în ceea ce priveşte potenţialul de acţiune antiviral pe SARS-CoV-2 al numeroşi fitocompuşi. Din studiile analizate, reiese faptul că fitoterapia poate constitui o metodă alternativă şi complementară în prevenţia şi tratamentul COVID-19, în special la pacienţii cu simptomatologie uşoară şi moderată. Bibliografia cu siguranţă este mult mai vastă, numeroase studii aflându-se încă în procedura de peer review sau în limbi ce nu sunt de circulaţie internaţională. Sperăm ca această incursiune să fi trezit interesul şi înclinaţia cercetătorilor şi pentru fitoterapie, ca aliat în lupta comună împotriva noului coronavirus. Studiile in silico au contribuit la proiectarea medicamentelor asistate de computer şi reprezintă un instrument valoros şi în cercetările pe fitomolecule, mai puţin costisitoare şi de orientare pentru viitoarele studii in vitro sau in vivo. Extinderea proprietăţilor antivirale deja recunoscute ale unor plante medicinale asupra SARS-CoV-2 este utilă, dar nu suficientă. Studiile in silico prezentate în această revizie de literatură efectuată ne etalează numeroase plante şi fitocompuşi cu un potenţial antiviral semnificativ în ceea ce priveşte noul coronavirus. De asemenea, există studii clinice în desfăşurare şi unele ce tocmai s-au încheiat, ale căror rezultate le aşteptăm cu deosebit interes. Puţinele studii clinice efectuate deja ne demonstrează efectul pozitiv al tratamentelor bazate pe plante în diminuarea simptomatologiei, scurtarea perioadei de convalescenţă şi îmbunătăţirea parametrilor biologici şi imagistici. Este însă nevoie de continuarea cercetărilor prin studii clinice mai ample, cu criterii şi standarde bine definite.

\section{BIBLIOGRAFIE}

1. Ahmad T, Khan M, Haroon et al. COVID-19: Zoonotic aspects. Travel Med Infect Dis. 2020; 36:101607.

2. Walsh KA, Spillane $S$, Comber $L$ et al. The duration of infectiousness of individuals infected with SARS-CoV-2. $J$ Infect. 2020 Oct 10;S01634453(20)30651-4.

3. Wang $\mathrm{H}$, Wang L, Lee EH et al. Decoding COVID-19 pneumonia: comparison of
Conflict of interest: none declared Financial support: none declared

deep learning and radiomics CT image signatures. Eur J Nucl Med Mol Imaging. 2020 Oct 23;1-9.

4. Giavedoni P, Podlipnik S, Pericàs JM et al. Skin Manifestations in COVID-19: 
Prevalence and Relationship with Disease Severity. J Clin Med. 2020 Oct 12; 9(10):E3261.

5. Leru PM, Neguleț IE, Anton VF et al. Manifestări cutanate în COVID-19 forme clinice și diagnostic diferențial. Ro J Med Pract. 2020;15(3):292-296.

6. Wang JG, Cui HR, Tang HB et al. Gastrointestinal symptoms and fecal nucleic acid testing of children with 2019 coronavirus disease: a systematic review and meta-analysis. Sci Rep. 2020 Oct 20;10(1):17846.

7. Luo X, Zhou GZ, Zhang $Y$ et al. Coronaviruses and gastrointestinal diseases. Mil Med Res. 2020 Oct 14;7(1):49.

8. Kunutsor SK, Laukkanen JA. Renal complications in COVID-19: a systematic review and meta-analysis. Ann Med. 2020 Nov;52(7):345-353.

9. Favas TT, Dev P, Chaurasia RN et al. Neurological manifestations of COVID-19: a systematic review and meta-analysis of proportions. Neurol Sci. 2020 Oct 21;1-34.

10. Parra A, Juanes A, Losada CP et al. Psychotic symptoms in COVID-19 patients. A retrospective descriptive study. Psychiatry Res. 2020 Sep;291:113254.

11. Khadke S, Ahmed N, Ahmed $\mathrm{N}$ et al. Harnessing the immune system to overcome cytokine storm and reduce viral load in COVID-19: a review of the phases of illness and therapeutic agents. Virol J. 2020 Oct 15;17(1):154.

12. Ikewaki N, Rao KS, Archibold AD et al. Coagulopathy associated with COVID-19 - Perspectives \& Preventive strategies using a biological response modifier Glucan. Thromb J. 2020 Oct 16;18:27.

13. Ji HL, Zhao R, Matalon $S$ et al. Elevated Plasmin(ogen) as a Common Risk Factor for COVID-19 Susceptibility. Physiol Rev. 2020; 100(3):1065-1075.

14. Singhal T. A Review of Coronavirus Disease-2019 (COVID-19). The Indian Journal of Pediatrics. 2020; 87(4):281-286.

15. Kosmeri C, Koumpis E, Tsabouri S et al. Hematological manifestations of SARS-CoV-2 in children. Pediatr Blood Cancer. 2020 dec;67(12):e28745.

16. Babayeva M, Loewy Z. Repurposing Drugs for COVID-19: Pharmacokinetics and Pharmacogenomics of Chloroquine and Hydroxychloroquine. Pharmgenomics Pers Med. 2020 Oct 23;13:531-542.

17. Edwards JK, Cole SR, Adimora AA. Remdesivir and COVID-19. Lancet. 2020 Oct 3;396(10256):953.

18. Chai KL, Valk SJ, Piechotta V et al. Convalescent plasma or hyperimmune immunoglobulin for people with COVID-19: a living systematic review. Cochrane Database Syst Rev. 2020 Oct 12;10:CD013600.

19. Chilimuri S, Sun H, Alemam A et al. Tocilizumab use in patients with moderate to severe COVID-19: A retrospective cohort study. J Clin Pharm Ther. 2020

Oct 24.

20. Ucciferri C, Vecchiet J, Falasca K. Role of monoclonal antibody drugs in the treatment of COVID-19. World J Clin Cases. 2020 Oct 6;8(19):4280-4285.

21. Kostoff RN, Kanduc D, Porter AL et al. Vaccine - and natural infection-induced mechanisms that could modulate vaccine safety. Toxicol Rep. 2020 Oct 22.

22. Pecora F, Persico F, Argentiero A et al. The Role of Micronutrients in Support of the Immune Response against Viral Infections. Nutrients. 2020 Oct 20;12(10):3198.

23. Junaid K, Ejaz H, Abdalla AE et al. Effective Immune Functions of Micronutrients against SARS-CoV-2. Nutrients. 2020 Sep 29;12(10):E2992.

24. Honore PM, Gutierrez LB, Kugener L et al. SARS-CoV-2 infection as a risk factor for herpesviridae reactivation: consider the potential influence of corticosteroid therapy. Crit Care. 2020 Oct 22;24(1):623.

25. Bansal P, Goyal A, Cusick A et al. Hydroxychloroquine: A comprehensive review and its controversial role in coronavirus disease 2019. Ann Med. 2020 Oct 23:1-35.

26. Garcia P, Revet A, Yrondi A et al. Psychiatric Disorders and Hydroxychloroquine for Coronavirus Disease 2019 (COVID-19): A VigiBase Study. Drug Saf. 2020 Oct 19:1-8.

27. Audrey F, Delphine V, Serena R et al. Spontaneous reported cardiotoxicity induced by lopinavir/ritonavir in COVID-19. An alleged past-resolved problem. Int J Cardiol. 2020 Oct 16:S0167-5273(20)33981-4.

28. Takahashi T, Luzum JA, Nicol MR et al. Pharmacogenomics of COVID-19 therapies. NPJ Genom Med. 2020 Aug 18:5:35.

29. Pujari R, Thommana MV, Ruiz Mercedes $B$ et al. Therapeutic Options for COVID-19: A Review. Cureus. 2020 Sep 16;12(9):e10480.

30. https://www.afro.who.int/news/expertpanel-endorses-protocol-covid-19-herbalmedicine-clinical-trials?fbclid=IwAR29bA DYsmqfEFkyjFg97RyUTuJbpntGfpH2RSzQ5G-iaAXp308wkMtpCA.

31. Lau JTF, Leun PC et al. The Use of an Herbal Formula by Hospital Care Workers During the Severe Acute Respiratory Syndrome Epidemic in Hong Kong to Prevent Severe Acute Respiratory Syndrome Transmission, Relieve Influenza-Related Symptoms, and Improve Quality of Life: A Prospective Cohort Study. The Journal of Alternative and Complementary Medicine Feb 2005;49-55.

32. Bhuiyan FR, Howlader S, Raihan T et al. Plants Metabolites: Possibility of Natural Therapeutics Against the COVID-19 Pandemic. Review article. Front. Med. 2020 August 07.
33. Jahan I, Onay A. Potentials of plantbased substance to inhabit and probable cure for the COVID-19. Turk J Biol. 2020 Jun 21;44(3):228-241.

34. Shahzad F, Anderson D, Najafzadeh M. The Antiviral, Anti-Inflammatory Effects of Natural Medicinal Herbs and Mushrooms and SARS-CoV-2 Infection. Nutrients. 2020;12(9):2573.

35. Shahrajabian HM, Sun W, Shen $\mathrm{H}$ et al. Chinese herbal medicine for SARS and SARS-CoV-2 treatment and prevention, encouraging using herbal medicine for COVID-19 outbreak. Acta Agriculturae Scandinavica, Section B - Soil \& Plant Science 2020;70(5):437-443.

36. Yang $\mathrm{Y}$, Islam MS, Wang $\mathrm{J}$ et al. Traditional Chinese Medicine in the Treatment of Patients Infected with 2019-New Coronavirus (SARS-CoV-2): A Review and Perspective. Int J Biol Sci. 2020;16(10):1708/1717.

37. Gurung AB, Ali MA, Lee J et al. Unravelling lead antiviral phytochemicals for the inhibition of SARS-CoV-2 Mpro enzyme through in silico approach. Life Sci. 2020 Aug 15;255:117831.

38. He J, Hu L, Huang X et al. Potential of coronavirus $3 \mathrm{C}$-like protease inhibitors for the development of new anti-SARSCoV-2 drugs: Insights from structures of protease and inhibitors. International Journal of Antimicrobial Agents. 2020;56(2):106055.

39. 39.Sharma N, Muthamilarasan M, Prasad A et al. Genomics approaches to synthesize plant-based biomolecules for therapeutic applications to combat SARS-CoV-2. 2020;112 (6): 4322-4331.

40. Suzutani T, Ogasawara M, Yoshida I et al. Anti-herpesvirus activity of an extract of Ribes nigrum L. Phytother Res. 2003 Jun;17(6):609-13.

41. Knox YM, Suzutani T, Yosida I et al. Anti-influenza virus activity of crude extract of Ribes nigrum L. Phytother Res. 2003 Feb;17(2):120-2.

42. Knox YM, Hayashi K, Suzutani T et al. Activity of anthocyanins from fruit extract of Ribes nigrum L. against influenza $A$ and B viruses. Acta Virol. 2001; 45(4):209-15.

43. Schneider S, Reichling J, Stintzing FC et al. Anti-herpetic properties of hydroalcoholic extracts and pressed juice from Echinacea pallida. Planta Med. 2010 Feb;76(3):265-72.

44. Binns SE, Hudson J, Merali S et al. Antiviral activity of characterized extracts from echinacea spp. (Heliantheae: Asteraceae) against herpes simplex virus (HSV-I). Planta Med. 2002 Sep; 68(9):780-3.

45. Gabriele J. Kembuan et al. Potential usage of immune-modulating supplements of the Echinacea genus for COVID-19 infection. International Journal of Medical Reviews and Case Reports. 2020;4(9):11-15. 
46. Schnitzler P, Nolkemper S, Stintzing FC et al. Comparative in vitro study on the anti-herpetic effect of phytochemically characterized aqueous and ethanolic extracts of Salvia officinalis grown at two different locations. Phytomedicine. 2008 Jan;15(1-2):62-70.

47. Wang $Z Y, L i Y Q$, Guo $Z W$ et al. ERK1/2-HNF4 $\alpha$ axis is involved in epigallocatechin-3-gallate inhibition of HBV replication. Acta Pharmacol Sin. 2020 Feb;41(2):278-285.

48. Falcó I, Randazzo W, Rodríguez-Díaz J et al. Antiviral activity of aged green tea extract in model food systems and under gastric conditions. Int J Food Microbiol. 2019 Mar 2;292:101-106.

49. Tragoolpua $Y$, Jatisatienr A. Anti-herpes simplex virus activities of Eugenia caryophyllus (Spreng.) Bullock \& S. G. Harrison and essential oil, eugenol. Phytother Res. 2007 Dec;21(12):1153-8.

50. Aboubakr HA, Nauertz A, Luong NT et al. In Vitro Antiviral Activity of Clove and Ginger Aqueous Extracts against Feline Calicivirus, a Surrogate for Human Norovirus. J Food Prot. 2016 Jun; 79(6):1001-12.

51. Chiang LC, Ng LT, Cheng PW et al. Antiviral activities of extracts and selected pure constituents of Ocimum basilicum. Clin Exp Pharmacol Physiol. 2005 Oct; 32(10):811-6.

52. Torelli A, Gianchecchi E, Piccirella S et al. Sea buckthorn bud extract displays activity against cell-cultured Influenza virus. J Prev Med Hyg. 2015 Aug 5;56(2):E51-6.

53. Rouf R, Uddin SJ, Sarker DK et al. Antiviral potential of garlic (Allium sativum) and its organosulfur compounds: A systematic update of pre-clinical and clinical data. Trends Food Sci Technol. 2020 Oct;104:219-234.

54. Dorsch W, Ring J. Anti-inflammatory substances from onions could be an option for treatment of COVID-19-a hypothesis. Allergo J Int. 2020 Oct 20:1-2.

55. Lee JB, Miyake S, Umetsu et al. Anti-influenza A virus effects of fructan from Welsh onion (Allium fistulosum L.). Food Chem. 2012 Oct 15;134(4):2164-8.

56. Camero M, Lanave $\mathrm{G}$, Catella $\mathrm{C}$ et al. Virucidal activity of ginger essential oil against caprine alphaherpesvirus-1. Vet Microbiol. 2019 Mar;230:150-155.

57. Chang JS, Wang KC, Yeh CF et al. Fresh ginger (Zingiber officinale) has anti-viral activity against human respiratory syncytial virus in human respiratory tract cell lines. J Ethnopharmacol. 2013 Jan 9;145(1):146-51.

58. Verma RK, Kumari P, Maurya RK et al. Medicinal properties of turmeric (Curcuma longa L.): A review. International Journal of Chemical Studies 2018;6(4):1354-1357.

59. Chiang LC, Chiang W, Chang MY et al. Antiviral activity of Plantago major extracts and related compounds in vitro. Antiviral Res. 2002 Jul;55(1):53-62.

60. Glatthaar-Saalmüller B, Fal AM, Schönknecht K et al. Antiviral activity of an aqueous extract derived from Aloe arborescens Mill. against a broad panel of viruses causing infections of the upper respiratory tract. Phytomedicine. 2015 Sep 15;22(10):911-20.

61. Feng X, Cao S, Qiu F et al. Traditional application and modern pharmacological research of Artemisia annua $L$. Pharmacol Ther. 2020 Aug 3:107650.

62. Joshi SS, Su X, D'Souza DH. Antiviral effects of grape seed extract against feline calicivirus, murine norovirus, and hepatitis A virus in model food systems and under gastric conditions. Food Microbiol. 2015 Dec;52:1-10. doi: 10.1016/j.fm.2015.05.011

63. Micol V, Caturla N, Pérez-Fons L et al. The olive leaf extract exhibits antiviral activity against viral haemorrhagic septicaemia rhabdovirus (VHSV). Antiviral Res. 2005 Jun;66(2-3):129-36.

64. Pastorino G, Cornara L, Soares S et al. Liquorice (Glycyrrhiza glabra): A phytochemical and pharmacological review. Phytother Res. 2018 Dec; 32(12):2323-2339.

65. Zhao C, Gao L, Wang $C$ et al. Structural characterization and antiviral activity of a novel heteropolysaccharide isolated from Grifola frondosa against enterovirus 71. Carbohydr Polym. 2016 Jun 25; 144:382-9.

66. Ren G, Xu L, Lu T et al. Structural characterization and antiviral activity of lentinan from Lentinus edodes mycelia against infectious hematopoietic necrosis virus. Int J Biol Macromol. 2018 Aug; 115:1202-1210.

67. Shahzad F, Anderson D, Najafzadeh M. The Antiviral, Anti-Inflammatory Effects of Natural Medicinal Herbs and Mushrooms and SARS-CoV-2 Infection. Nutrients. 2020 Aug 25;12(9):2573.

68. Castillo E, Duarte LF, Corrales $\mathrm{N}$ et al. Anti-herpetic Activity of Macrocystis pyrifera and Durvillaea antarctica Algae Extracts Against HSV-1 and HSV-2. Front Microbiol. 2020 Sep 11;11:2006.

69. Liang $\mathrm{H}$, Ruan $\mathrm{H}$, Ouyang $\mathrm{Q}$ et al. Herb-target interaction network analysis helps to disclose molecular mechanism of traditional Chinese medicine. Sci Rep. 2016 Nov 11;6:36767.

70. Sarkar L, Putchala RK, Safiriyu AA et al. Azadirachta indica A. Juss Ameliorates Mouse Hepatitis Virus-Induced Neuroinflammatory Demyelination by Modulating Cell-to-Cell Fusion in an Experimental Animal Model of Multiple Sclerosis. Front Cell Neurosci. 2020 May 12;14:116.

71. Roy S, Bhattacharyya P. Possible role of traditional medicinal plant Neem (Azadirachta indica) for the management of COVID-19 infection. International Journal of Research in Pharmaceutical
Sciences. 2020: 11(SPL1), 122-125.

72. Nolkemper S, Reichling J, Sensch KH et al. Mechanism of herpes simplex virus type 2 suppression by propolis extracts. Phytomedicine. 2010 Feb;17(2):132-8.

73. Bachevski D, Damevska K, Simeonovski V, Dimova M. Back to the basics: Propolis and COVID-19. Dermatol Ther. 2020 Jul;33(4):e13780.

74. Badjakov I, Nikolova M, Gevrenova $V$ et al. Bioactive compounds in small Fruits and their Influence on Human Health. Biotechnology \& Biotechnological Equipment 2008;22(1):581-587.

75. Gansukh E, Nile A, Kim DH et al. New insights into antiviral and cytotoxic potential of quercetin and its derivatives - A biochemical perspective. Food Chem. 2021 Jan 1:334:127508.

76. Derosa G, Maffioli P, D'Angelo A et al. A role for quercetin in coronavirus disease 2019 (COVID-19). Phytother Res. 2020 Oct 9 .

77. Latif R, Wang CY. Andrographolide as a potent and promising antiviral agent. Chin J Nat Med. 2020 Oct;18(10):760-769.

78. Sun ZG, Zhao TT, Lu N et al. Research Progress of Glycyrrhizic Acid on Antiviral Activity. Mini Rev Med Chem. 2019; 19(10):826-832.

79. Yang F, Feng C, Yao et al. Antiviral effect of baicalin on Marek's disease virus in CEF cells. BMC Vet Res. 2020 Oct 2;16(1):371.

80. Geng P, Zhu H, Zhou W et al. Baicalin Inhibits Influenza A Virus Infection via Promotion of M1 Macrophage Polarization. Front Pharmacol. 2020 Oct 6;11:01298.

81. Yan $\mathrm{H}, \mathrm{Ma} \mathrm{L}$, Wang $\mathrm{H}$ et al. Luteolin decreases the yield of influenza $A$ virus in vitro by interfering with the coat protein I complex expression. J Nat Med. 2019 Jun;73(3):487-496.

82. Theoharides TC. COVID-19, pulmonary mast cells, cytokine storms, and beneficial actions of luteolin. Biofactors. 2020 May;46(3):306-308.

83. Abba $\mathrm{Y}, \mathrm{Hassim} \mathrm{H}$, Hamzah $\mathrm{H}$ et al. Antiviral Activity of Resveratrol against Human and Animal Viruses. Adv Virol. 2015;2015:184241.

84. Marinella MA. Indomethacin and resveratrol as potential treatment adjuncts for SARS-CoV-2/COVID-19. Int J Clin Pract. 2020 Sep;74(9):e13535.

85. Yang XX, Li CM, Huang CZ. Curcumin modified silver nanoparticles for highly efficient inhibition of respiratory syncytial virus infection. Nanoscale. 2016 Feb 7;8(5):3040-8.

86. Jennings MR, Parks RJ. Antiviral Effects of Curcumin on Adenovirus Replication. Microorganisms. 2020 Oct 4;8(10):E1524.

87. Hesari A, Ghasemi F, Salarinia R et al. Effects of curcumin on NF-kB, AP-1, and $W n t / \beta$-catenin signaling pathway in hepatitis B virus infection. J Cell Biochem. 2018 Nov;119(10):7898-7904. 
88. Lane T, Anantpadma M, Freundlich JS et al. The Natural Product Eugenol Is an Inhibitor of the Ebola Virus In Vitro. Pharm Res. 2019 May 17;36(7):104.

89. Romero MR, Serrano MA, Vallejo M et al. Antiviral effect of artemisinin from Artemisia annua against a model member of the Flaviviridae family, the bovine viral diarrhoea virus (BVDV). Planta Med. 2006 Oct;72(13):1169-74.

90. Kaihatsu K, Yamabe M, Ebara Y. Antiviral Mechanism of Action of Epigallocatechin3-O-gallate and Its Fatty Acid Esters. Molecules. 2018 Sep 27;23(10):2475.

91. Oo A, Hassandarvish P, Chin SP et al. In silico study on anti-Chikungunya virus activity of hesperetin. PeerJ. 2016 Oct 26;4:e2602.

92. Knox YM, Hayashi K, Suzutani T et al. Activity of anthocyanins from fruit extract of Ribes nigrum $L$. against influenza $A$ and B viruses. Acta Virologica. 2001; 45(4):209-215.

93. Huang F, Li Y, Lai-Han Leung E et al. A review of therapeutic agents and Chinese herbal medicines against SARS-COV-2 (COVID-19). Pharmacol Res. 2020 Aug;158:104929.

94. Xiong X, Wang P, Su K et al. Chinese herbal medicine for coronavirus disease 2019: A systematic review and metaanalysis. Pharmacol Res. 2020 Oct; 160:105056.

95. Zhong LLD, Lam WC, Yang W et al. Potential Targets for Treatment of Coronavirus Disease 2019 (COVID-19): A Review of Qing-Fei-Pai-Du-Tang and Its Major Herbs. Am J Chin Med. 2020; 48(5):1051-1071.

96. Tao Z, Zhang L, Friedemann T et al. Systematic analyses on the potential immune and anti-inflammatory mechanisms of Shufeng Jiedu Capsule against Severe Acute Respiratory Syndrome Coronavirus 2 (SARS-CoV-2)caused pneumonia. Journal of Functional Foods. 2020;75;104243.

97. Dowlati Beirami A, Hatamabadi D, Iranpanah $S$ et al. In Silico Identification of Potentially Effective Herbal Inhibitors of SARS-Cov-2 Main Protease by Virtual Screening Method: Potential AntiCOVID-19 Molecules. Sch Med Stud J. 2020 Sep.7;2(3):2-6.

98. Liu Z, Li X, Gou C et al. Effect of Jinhua Qinggan granules on novel coronavirus pneumonia in patients. $J$ Tradit Chin Med. 2020 Jun;40(3):467-472.

99. Zhang HT, Huang MX, Liu X et al. Evaluation of the Adjuvant Efficacy of Natural Herbal Medicine on COVID-19: A Retrospective Matched Case-Control Study. Am J Chin Med. 2020; 48(4):779-792.

100. Chowdhury P. In silico investigation of phytoconstituents from Indian medicinal herb 'Tinospora cordifolia (giloy)' against SARS-CoV-2 (COVID-19) by molecular dynamics approach. J Biomol Struct Dyn. 2020:1-18.
101. et al. Targeting COVID-19 (SARS-CoV-2) main protease through active phytochemicals of ayurvedic medicinal plants - Withania somnifera (Ashwagandha), Tinospora cordifolia (Giloy) and Ocimum sanctum (Tulsi) - a molecular docking study. J Biomol Struct Dyn. 2020:1-14.

102. Kumar V, Dhanjal JK, Kaul SC et al. Withanone and caffeic acid phenethyl ester are predicted to interact with main protease (Mpro) of SARS-CoV-2 and inhibit its activity. Journal of Biomolecular Structure and Dynamics 2020.

103. Güler HI, Tatar G, Yildiz O et al.. Investigation of potential inhibitor properties of ethanolic propolis extracts against ACE-II receptors for COVID-19 treatment by Molecular Docking Study. Abstract.

104. Vipul Kumar, Jaspreet Kaur Dhanjal, Sunil C. Kaul, Renu Wadhwa, Durai Sundar. Withanone and caffeic acid phenethyl ester are predicted to interact with main protease (Mpro) of SARSCoV-2 and inhibit its activity. Journal of Biomolecular Structure and Dynamics 2020.

105. Ibrahim MAA, Abdelrahman AHM, Hussien TA et al. In silico drug discovery of major metabolites from spices as SARS-CoV-2 main protease inhibitors. Computers in Biology and Medicine. 2020 Nov;126: 104046.

106. Baildya N, Khan AA, Ghosh NN et al. Screening of potential drug from Azadiractha Indica (Neem) extracts for SARS-CoV-2: An insight from molecular docking and MD-simulation studies. $J \mathrm{Mol}$ Struct. 2020 Oct 3:129390.

107. Borkotoky S, Banerjee M. A computational prediction of SARS-CoV-2 structural protein inhibitors from Azadirachta indica (Neem). J Biomol Struct Dyn. 2020 May 28:1-17.

108. Dey D, Borkotoky S, Banerjee M. In silico identification of Tretinoin as a SARSCoV-2 envelope (E) protein ion channel inhibitor. Comput Biol Med. 2020 Oct 20;127:104063.

109. Gupta MK, Vemula S, Donde R et al. In-silico approaches to detect inhibitors of the human severe acute respiratory syndrome coronavirus envelope protein ion channel. J. Biomol. Struct. Dyn. 2020

110. Ghosh R, Chakraborty A, Biswas A et al. Identification of alkaloids from Justicia adhatoda as potent SARS CoV-2 main protease inhibitors: An in silico perspective. J Mol Struct. 2020 Oct 19:129489.

111. Lakshmi SA, Shafreen RMB, Priya A et al. Ethnomedicines of Indian origin for combating COVID-19 infection by hampering the viral replication: using structure-based drug discovery approach. Journal of Biomolecular Structure and Dynamics. 2020.
112. Ghosh R, Chakraborty A, Biswas A et al. Identification of polyphenols from Broussonetia papyrifera as SARS CoV-2 main protease inhibitors using in silico docking and molecular dynamics simulation approaches. J Biomol Struct Dyn. 2020 Aug 7:1-14.

113. Park J Y, Yuk HJ, Ryu HW et al. Evaluation of polyphenols from Broussonetia papyrifera as coronavirus protease inhibitors. Journal of Enzyme Inhibition and Medicinal Chemistry. 2017: 32 (1), 504-515.

114. Ghosh R, Chakraborty A, Biswas A et al. Computer aided identification of potential SARS CoV-2 main protease inhibitors from diterpenoids and biflavonoids of Torreya nucifera leaves. J Biomol Struct Dyn. 2020 Nov 3:1-16.

115. Elfiky AA. Natural products may interfere with SARS-CoV-2 attachment to the host cell. Journal of Biomolecular Structure and Dynamics. 2020.

116. Bhardwaj VK, Singh R, Sharma J et al. Identification of bioactive molecules from tea plant as SARS-CoV-2 main protease inhibitors. Journal of Biomolecular Structure and Dynamics.2020.

117. Ghosh R, Chakraborty A, Biswas A et al. Evaluation of green tea polyphenols as novel corona virus (SARS CoV-2) main protease (Mpro) inhibitors - an in silico docking and molecular dynamics simulation study. J Biomol Struct Dyn. 2020 Jun 22:1-13.

118. Maiti S, Banerjee A. Epigallocatechin gallate and theaflavin gallate interaction in SARS-CoV-2 spike-protein central channel with reference to the hydroxychloroquine interaction: Bioinformatics and molecular docking study. Drug Dev Res. 2020 Aug 7.

119. Sharma P, Shanavas A. Natural derivatives with dual binding potential against SARS-CoV-2 main protease and human ACE2 possess low oral bioavailability: a brief computational analysis. J Biomol Struct Dyn. 2020 Jul 21:1-12.

120. Gyebi GA, Ogunro OB, Adegbenro P. Adegunloye AP et al. Potential inhibitors of coronavirus 3-chymotrypsin-like protease (3CLpro): an in silico screening of alkaloids and terpenoids from African medicinal plants, Journal of Biomolecular Structure and Dynamics. 2020.

121. Aanouz I, Belhassan A, El-Khatabi K et al. Moroccan Medicinal plants as inhibitors against SARS-CoV-2 main protease: Computational investigations, Journal of Biomolecular Structure and Dynamics. 2020.

122. Islam R, Parves MR, Paul AS et al. A molecular modeling approach to identify effective antiviral phytochemicals against the main protease of SARS-CoV-2. Journal of Biomolecular Structure and Dynamics. 2020.

123. Gupta S, Singh V, Varadwaj PK et al. Secondary metabolites from spice and 
herbs as potential multitarget inhibitors of SARS-CoV-2 proteins. J Biomol Struct Dyn. 2020 Oct 27:1-20.

124. Choy KT, Wong AYL, Kaewpreedee P et al. Remdesivir, lopinavir, emetine and homoharringtonine inhibit SARS-CoV-2 replication in vitro. Antiviral Research. 2020; 178:104786.

125. Singh S, Sk MF, Sonawane A et al. Plant-derived natural polyphenols as potential antiviral drugs against SARS-CoV-2 via RNA-dependent RNA polymerase (RdRp) inhibition: an in-silico analysis. J Biomol Struct Dyn. 2020 Jul 28:1-16.

126. Yu S, Zhu Y, Xu J et al. Glycyrrhizic acid exerts inhibitory activity against the spike protein of SARS-CoV-2. Phytomedicine. 2020 Oct 2:153364.

127. Sinha SK, Prasad SK, Islam MA et al. Potential Leads from Liquorice against SARS-CoV-2 Main Protease using Molecular Docking Simulation Studies. Comb Chem High Throughput Screen. 2020 Aug 16.

128. Sinha SK, Prasad SK, Islam MA et al. Identification of bioactive compounds from Glycyrrhiza glabra as possible inhibitor of SARS-CoV-2 spike glycoprotein and non-structural protein-15: a pharmacoinformatics study. J Biomol Struct Dyn. 2020 Jun 18:1-15.

129. Br B, Damle H, Ganju S et al. In silico screening of known small molecules to bind ACE2 specific RBD on Spike glycoprotein of SARS-CoV-2 for repurposing against COVID-19. F1000Res. 2020 Jul 1;9:663.

130. Safa O, Hassani-Azad M, Farashahinejad $\mathrm{M}$ et al. Effects of Licorice on clinical symptoms and laboratory signs in moderately ill patients with pneumonia from COVID-19: A structured summary of a study protocol for a randomized controlled trial. Trials. 2020 Sep 15;21(1):790.

131. Murck H. Symptomatic Protective Action of Glycyrrhizin (Licorice) in COVID-19 Infection? Front Immunol. 2020 May 28;11:1239.

132. http://www.chictr.org.cn/showprojen. aspx?proj=49131.

133. http://www.chictr.org.cn/ historyversionpuben. aspx?regno=ChiCTR2000030490

134. Vardhan S, Sahoo SK. In silico ADMET and molecular docking study on searching potential inhibitors from limonoids and triterpenoids for COVID-19. Comput Biol Med. 2020 Sep;124:103936.

135. Ranjbar A, Jamshidi M, Torabi S. Molecular modelling of the antiviral action of Resveratrol derivatives against the activity of two novel SARS CoV-2 and 2019-nCoV receptors. Eur Rev Med Pharmacol Sci. 2020 Jul; 24(14):7834-7844.

136. Chowdhury MA, Shuvho MBA, Shahid MA et al. Prospect of biobased antiviral face mask to limit the coronavirus outbreak. Environ Res. 2020 Oct 3;192:110294.

137. Narkhede RR, Pise AV, Cheke RS et al. Recognition of Natural Products as Potential Inhibitors of COVID-19 Main Protease (Mpro): In-Silico Evidences. Nat Prod Bioprospect. 2020 Oct;10(5):297306.

138. Zaki AA, Al-Karmalawy AA, El-Amier YA et al. Molecular docking reveals the potential of Cleome amblyocarpa isolated compounds to inhibit COVID-19 virus main protease. New J Chem. 2020; 44:16752-16758.

139. Ma Q, Li R, Pan W et al. Phillyrin (KD-1) exerts anti-viral and anti-inflammatory activities against novel coronavirus (SARS-CoV-2) and human coronavirus 229E (HCoV-229E) by suppressing the nuclear factor kappa B (NF-kB) signaling pathway. Phytomedicine. 2020 Nov; 78:153296.

140. Kiran G, Karthik L, Shree Devi MS et al. In Silico computational screening of Kabasura Kudineer - Official Siddha Formulation and JACOM against SARS-CoV-2 spike protein. J Ayurveda Integr Med. 2020 May 25:S09759476(20)30024-3.

141. Shah A, Patel V, Parmar B. Discovery of Some Antiviral Natural products to fight against Novel Corona Virus (SARSCoV-2) using Insilico approach. Comb Chem High Throughput Screen. 2020 Sep 2.

142. Taofeek O. Molecular Docking and Admet Analyses of Photochemicals from Nigella sativa (blackseed), Trigonella foenumgraecum (Fenugreek) and Anona muricata (Soursop) on SARS-CoV-2 Target. Abstract.

143. Koshak AE, Koshak EA, Mobeireek AF et al. Nigella sativa supplementation to treat symptomatic mild COVID-19: A structured summary of a protocol for a randomised, controlled, clinical trial. Trials. 2020 Aug 8;21(1):703.

144. Alsaffar DF. In Silico Molecular Docking Studies of Medicinal Arabic Plant-Based Bioactive Compounds as a Promising Drug Candidate against COVID-19. International Journal of Innovative Science and Research Technology. 2020 May;5(5):876-896.

145. Caruso F, Rossi M, Pedersen JZ et al. Computational studies reveal mechanism by which quinone derivatives can inhibit SARS-CoV-2. Study of embelin and two therapeutic compounds of interest, methyl prednisolone and dexamethasone. Journal of Infection and Public Health.2020.

146. Iheagwam FN, Rotimi SO. ComputerAided Analysis of Multiple SARS-CoV-2 Therapeutic Targets: Identification of Potent Molecules from African Medicinal Plants. Scientifica.2020;1878410

147. Chikhale RV, Sinha SK, Patil RB et al. In-silico investigation of phytochemicals from Asparagus racemosus as plausible antiviral agent in COVID-19. Journal of Biomolecular Structure and Dynamics. 2020. DOI: 10.1080/07391102.2020.1784289

148. Rolta R, Yadav R, Salaria D et al. In silico screening of hundred phytocompounds of ten medicinal plants as potential inhibitors of nucleocapsid phosphoprotein of COVID-19: an approach to prevent virus assembly. Journal of Biomolecular Structure and Dynamics. 2020.

149. Fakhar Z, Faramarzi B, Pacifico S et al. Anthocyanin derivatives as potent inhibitors of SARS-CoV-2 main protease: An in-silico perspective of therapeutic targets against COVID-19 pandemic. Journal of Biomolecular Structure and Dynamics. 2020.

150. Azim KF, Ahmed SR, Banik A et al. Screening and druggability analysis of some plant metabolites against SARS-CoV-2: An integrative computational approach. Informatics in Medicine Unlocked. 2020; 20; 100367.

151. Safa $O$, Hassaniazad M, Farashahinejad $M$ et al. Effects of Ginger on clinical manifestations and paraclinical features of patients with Severe Acute Respiratory Syndrome due to COVID-19: A structured summary of a study protocol for a randomized controlled trial. Trials. 2020 Oct 9;21(1):841.

152. https://www.irct.ir/trial/48114.

153. Omotuyi IO, Nash O, Ajiboye BO et al. Aframomum melegueta secondary metabolites exhibit polypharmacology against SARS-CoV-2 drug targets: in vitro validation of furin inhibition. Phytother Res. 2020 Sep 22. Abstract.

154. Da Sllva JKR, Figueiredo PLB, Byler KG et al. Essential Oils as Antiviral Agents. Potential of Essential Oils to Treat SARS-CoV-2 Infection: An In-Silico Investigation. Int J Mol Sci. 2020;21:3426.

155. Ogidigo JO, Iwuchukwu EA, Ibeji CU et al. Natural phyto, compounds as possible noncovalent inhibitors against SARSCoV2 protease: computational approach. J Biomol Struct Dyn. 2020 Oct 25:1-18.

156. Mohammadi S, Heidarizadeh M, Entesari $M$ et al. In silico Investigation on the Inhibiting Role of Nicotine/Caffeine by Blocking the S Protein of SARS-CoV-2 Versus ACE2 Receptor. Microorganisms. 2020 Oct 17;8(10):1600.

157. Farsalinos K, Eliopoulos E, Leonidas DD et al. Nicotinic Cholinergic System and COVID-19: In Silico Identification of an Interaction between SARS-CoV-2 and Nicotinic Receptors with Potential Therapeutic Targeting Implications. Int J Mol Sci. 2020 Aug 13;21(16):5807.

158. Beyazit $F$, Beyazit $Y$, Tanoglu A et al. Ankaferd hemostat (ABS) as a potential mucosal topical agent for the management of COVID-19 syndrome based on its PAR-1 inhibitory effect and oestrogen content. Med Hypotheses. 2020 Oct;143:110150. 
159. Colalto C. Volatile molecules for COVID-19: A possible pharmacological strategy? Drug Dev Res. 2020 Jul 19:10.1002/ddr.21716.

160. Chen RR, Li YJ, Chen JJ et al. A review for natural polysaccharides with anti-pulmonary fibrosis properties, which may benefit to patients infected by 2019-nCoV. Carbohydrate Polymers. 2020;247:116740.

161. Rattanapisit K, Shanmugaraj B, Manopwisedjaroen S et al. Rapid production of SARS-CoV-2 receptor binding domain (RBD) and spike specific monoclonal antibody CR3022 in

Nicotiana benthamiana. Sci Rep. 2020 Oct 19;10(1):17698

162. Garcia S. Pandemics and Traditional Plant-Based Remedies. A HistoricalBotanical Review in the Era of COVID-19. Front Plant Sci. 2020 Aug 28;11:571042. 